Mariusz Oziębłowski

Uniwersytet Humanistyczno-Przyrodniczy im. Jana Długosza, Częstochowa ORCID 0000-0003-3731-2799

e-mail: mozibowski@gmail.com

\title{
Funkcje sztuki w teorii Czystej Formy Stanisława lgnacego Witkiewicza
}

DOI: http://dx.doi.org/10.12775/RF.2019.005

Przedmiotem niniejszego tekstu jest analiza funkcji pełnionych przez sztukę w ramach teorii Czystej Formy Stanisława Ignacego Witkiewicza. Analiza ta będzie prowadzona przy użyciu kategorii i idei wypracowanych przez Hansa-Georga Gadamera w jego filozofii hermeneutycznej. Celem analiz jest wykazanie, że w postulowanej przez Witkiewicza koncepcji sztuki formistycznej, mimo narzucających się analogii z modernistyczną ideą sztuki autotelicznej, wolnej od pozaestetycznych związków ze światem życia praktycznego, dzieło sztuki pełni bardzo istotne funkcje pozaestetyczne. Po pierwsze, generuje i obiektywizuje specyficzny rodzaj doświadczenia dziejowości, tj. doświadczenie katastrofy, po drugie, jest narzędziem kontestacji procesów sensotwórczych, stanowiących istotę procesu nowożytnej modernizacji świata.

\section{Elementy hermeneutyczne}

W naszych analizach odwołamy się przede wszystkim do Gadamerowskiego odróżnienia dwóch aspektów doświadczenia hermeneutycznego. Zgodnie z nim nowożytna postać doświadczenia, czyli eksperyment naukowy, stanowi efekt procesu obiektywizacji eliminującej z pierwotnej struktury doświadczenia elementy składające się na jego aspekt ne- 
gatywny ${ }^{1}$. Pozytywny aspekt doświadczenia jest związany z klasyczną koncepcją prawdy, w której o wartości poznawczej teorii stanowi stopień jej zgodności z rzeczywistością ${ }^{2}$ tymczasem $\mathrm{w}$ aspekcie negatywnym mamy do czynienia z prawdą aletheiczna, pojmowaną jako otwartość bytu³.

Prócz tego przywołamy tezy, zgodnie z którymi sztuka pełni dwie funkcje kluczowe dla procesu stanowienia społecznych struktur sensu. Pierwsza to funkcja poznawcza, która realizuje się, gdy w doświadczeniu sztuki, w momencie przemiany gry w wytwór (Verwandlung ins Gebilde) rzeczywistość zostaje podniesiona do swej prawdy ${ }^{4}$. Oczywiście $\mathrm{w}$ tym przypadku mowa o prawdzie aletheicznej. Równie istotna jak poznawcza jest funkcja integrująca. Efekt doświadczenia sztuki to bowiem sensotwórcza integracja uczestników owego doświadczenia, obiektywizująca się w postaci konkretnej wspólnoty rozumienia.

Niezależnie od tego, czy nośnikiem formowania i kształtowania dzieła jest gotowa, oczywista wspólnota naszego widzenia świata sztuki, czy też dopiero mając wytwór, z którym się konfrontujemy, musimy nauczyć się „sylabizowania”, tzn. poznać alfabet i język tego, kto tutaj do nas mówi, istotne pozostaje to, że w każdym przypadku jest to wspólne dokonanie, tworzenie potencjalnej wspólnoty ${ }^{5}$.

Dla naszych rozważań szczególnie istotna jest komplementarność funkcji poznawczej i integrującej. Integracja wspólnot sensu dokonuje się w trakcie bytowego procesu prezentacji (Seinsvorganges der Darstellung) wyznaczającego centrum struktury doświadczenia sztuki ${ }^{6}$. Realizacja funkcji poznawczej jest fundamentem działania funkcji integrującej. Dlatego też w hermeneutyce Gadamera wszelkie rozumienie jest współrozumieniem - „kontynuacją rozmowy, która się zaczęła przed nami"7.

Tak określona restytucja poznawczej wartości sztuki była wymierzona przeciwko procesowi subiektywizacji estetyki ${ }^{8}$, którego efektem stała się nowoczesna koncepcja sztuki nieprzedstawiającej - wolnej od

1 Hans-Georg Gadamer, Prawda i metoda. Zarys hermeneutyki filozoficznej, przeł. Bogdan Baran (Warszawa: PWN, 2004), 473.

2 Tegoż, Rozum, słowo, dzieje. Szkice wybrane, przeł. Małgorzata Łukasiewicz, Krzysztof Michalski (Warszawa: PIW 2000), 39.

3 Tegoż, Prawda, 494.

4 Tamże, 173.

5 Tegoż, Aktualność piękna. Sztuka jako gra, symbol i święto, przeł. Krystyna Krzemieniowa (Warszawa: Oficyna Naukowa, 1993), 52.

6 Tegoż, Prawda, 177.

7 Jean Grondin, Wprowadzenie do hermeneutyki filozoficznej, przeł. Leszek Łysień (Kraków: Wydawnictwo WAM, 2007), 146.

8 Gadamer, Prawda, 79. 
wartości poznawczych oraz funkcji pozaestetycznych. W tej sytuacji filozofia hermeneutyczna winna unieważniać teorię Czystej Formy, której fundamentem jest przecież postulat suwerenności sztuki formistycznej względem wszelkich treści życiowych. Postaramy się pokazać, że tak nie jest. Sztuka formistyczna ma wartość poznawcza, wprawdzie negatywna, a nie pozytywna, bo zdefiniowaną w opozycji do klasycznej koncepcji prawdy, z pomoca kategorii Tajemnicy Istnienia. Jednak odwrotnie niż w hermeneutyce konsekwencją przyznania Czystej Formie wartości poznawczej staje się zakwestionowanie integrującej funkcji sztuki.

Spór pomiędzy hermeneutyką a teorią Czystej Formy dotyczy nie wartości poznawczej sztuki, lecz możliwości jej funkcji integrującej, w sytuacji gdy doświadczenie sztuki zostaje pojęte jako epifania prawdy negatywnej (odpowiednio: negatywnego aspektu doświadczenia hermeneutycznego i prawdy aletheicznej u Gadamera bądź Tajemnicy Istnienia u Witkiewicza). Oczywiście sporu tego nie rozstrzygniemy w niniejszym artykule. Postaramy się jednak przedstawić powody, dla których jako właściwą treść Czystej Formy należy wskazywać doświadczenie katastrofy. Konsekwencją zaś tegoż winno być porzucenie wszelkich marzeń o integrującej mocy sztuki.

\section{Przeciwieństwo formy i życia}

Istotnym elementem teorii Czystej Formy jest ostro zarysowana dychotomia sztuki realistycznej i formistycznej, przy czym znaczenia terminów „realizm” i "formizm”, jakich używa Witkiewicz, odbiegają od przyjętych w historii myśli estetycznej. Dla Stanisława Ignacego Witkiewicza, podobnie jak dla jego ojca, sztuka realistyczna to taka, o której wartości stanowiła prawdziwość odwzorowania rzeczywistości ${ }^{9}$. Takie rozumienie kategorii realizmu jest szersze od używanego w odniesieniu do polskiego malarstwa XIX wieku (gdzie „realizm” rodzajowych przedstawień z życia wsi i prostego ludu przeciwstawiano „idealizmowi" malarstwa romantycznego i akademickiego) ${ }^{10}$. Podobnie definicja sztuki formistycznej różni się od sposobu, w jaki pojmowano sztukę nieprzedstawiającą w obszarze dwudziestowiecznej awangardy. Jak po-

9 Stanisław Witkiewicz, O sztuce, krytyce artystycznej, stylu zakopiańskim, wybitnych twórcach, sprawach społecznych (Wrocław: Zakład Narodowy im. Ossolińskich, 1972), 82.

10 Jerzy Malinowski, Malarstwo polskie XIX wieku (Warszawa: Wydawnictwo DiG, 2003), 135. 
kazuje Maciej Soin, intencją Witkiewicza nie jest separowanie treści od formy dzieła, lecz minimalizacja znaczenia treści życiowych ${ }^{11}$.

Taka, samą przez się działającą formę, wywołującą estetyczne zadowolenie, nazywam Czystą Formą. Nie jest więc forma pozbawiona treści, bo takiej żaden żywy stwór stworzyć nie potrafi, tylko ta, w której życiowe składniki stanowią element drugorzędny ${ }^{12}$.

Kluczową dla teorii Czystej Formy dychotomią nie jest przeciwieństwo formy i treści, lecz przeciwstawienie sztuki i życia praktycznego. Ponieważ jednak sztuka formistyczna (czyli sztuka autentyczna) była definiowana przez Witkiewicza za pomocą kategorii „uczucia metafizycznego", jako podstawową dychotomię należałoby właściwie wskazać opozycję pragmatyki życia i metafizyki (również pojmowanej w specyficzny sposób).

Wprowadzając dychotomię realizmu i formizmu, Witkiewicz nie zamierzał reformować ani porządkować tradycyjnej terminologii, lecz bronił sztuki formistycznej przed atakami realistycznej krytyki. Opozycja realizmu i formizmu miała cel praktyczny - postulowała zastosowanie odpowiedniego, odmiennego niż w przypadku sztuki realistycznej, sposobu obioru dzieł formistycznych.

[...] należy wymagać od widzów i słuchaczy pewnego nastawienia na przyjmowanie formalnych, a nie życiowych wartości dzieł sztuki. Można to w dzisiejszych czasach presji naturalistycznej osiagnąć przez pouczenie ich o tym, na czym polega istota sztuki w ogóle, o czym wskutek wychowania i życia w atmosferze naturalizmu zapomnieli lub nie wiedzieli ${ }^{13}$.

Świadomość Witkiewicza, że postawa odbiorcy sztuki ma charakter aktywny i wpływa na sposób realizacji doświadczenia estetycznego, $\mathrm{w}$ zupełności odpowiada rozstrzygnięciom filozofii hermeneutycznej. Co więcej, przy formułowaniu warunków prawidłowej recepcji dzieła zostaje zastosowane pojęcie interpretacji. „Interpretując nieodpowiednio, można z doskonałej rzeczy formalnej zrobić realistyczną bujdę bez wartości, jak i dobry realistyczny dramat zamienić w formalny nonsens" ${ }^{\prime \prime}$.

11 Maciej Soin, Filozofia Stanisława Ignacego Witkiewicza (Wrocław: Wydawnictwo UW, 2002), 119.

12 Stanisław Ignacy Witkiewicz, O czystej formie i inne pisma o sztuce, oprac. Jan Leszczyński (Warszawa: PIW, 2003), 56.

13 Tamże, 65.

14 Tamże, 68. 
W dobie paninterpretacjonizmu świadomość związku pomiędzy rodzajem interpretacji a sposobem ukonstytuowania się jej przedmiotu nie jest niczym specjalnie niezwykłym, jednak teoria Czystej Formy była formułowana w epoce wiary w istnienie postrzeżeń protokolarnych. Należy zatem docenić przenikliwość jej autora.

Oczywiście Witkiewicz nie był żadnym paninterpretacjonistą. Z dzisiejszej perspektywy, z uwagi na jego metafizyczny realizm, należałoby określić go jako fundamentalistę (fundacjonistę). Niemniej doskonale zdawał sobie sprawę z aktywnego charakteru procesów poznawczych. Nie bez powodu posługiwał się pojęciem interpretacji na oznaczenie świadomego doboru wstępnych warunków doświadczenia sztuki.

Zgodnie z teza, iż „niemożliwe jest obiektywne ścisłe odgraniczenie realizmu od formizmu"15, dzieło sztuki należało traktować jako strukturę dwuaspektową - złożenie formy i treści życiowej (nawet dzieła stricte formistyczne nie mogły być uważane za wolne od domieszki uczuć życiowych $)^{16}$. Jeśli zatem kwalifikacja dzieła warunkująca przebieg doświadczenia sztuki miała zależeć od orientacji na określony typ wartości (praktycznej lub estetycznej) i polegała na eliminacji jednej z dwóch warstw dzieła (formalnej bądź życiowej), mamy pełne prawo w ramach teorii Czystej Formy odróżniać od siebie dwa sposoby interpretacji dzieł sztuki. Interpretacja realistyczna miałaby za cel piękno życiowe „związane z użytkowością życiową przedmiotu lub zjawiska"17, tymczasem interpretacja formistyczna byłaby zorientowana na piękno formalne, „które polega tylko na samym porządku, formie czy konstruktywności przedmiotu lub zjawiska"18.

Łącząc sposób doświadczania sztuki z pojęciem interpretacji, Witkiewicz twierdzi jednocześnie, że odbiór dzieła ma charakter spontanicznej, niedyskursywnej reakcji emocjonalnej ${ }^{19}$. Taki emocjonalizm estetyczny ewidentnie kłóci się z ideą interpretacji jako świadomej, racjonalnej, metodycznej procedury. Odpowiada jednak stanowisku filozofii hermeneutycznej, zgodnie z którym doświadczenie sztuki ma jednocześnie charakter bezpośredniego przeżycia i jest tożsame z procesem interpretacji. Hermeneutyczne utożsamienie doświadczenia i interpreta$\mathrm{cji}^{20}$ pozwala pokonać trudności, które rodzą się wraz z pytaniem o to, jak dyskursywna aktywność interpretowania może wpływać na bezpośrednie przeżywanie sztuki.

15 Tamże, 63.

16 Tamże, 70.

17 Tamże, 56.

18 Tamże.

19 Tamże.

20 Por.: ,[...] interpretacja pojęciowa to sposób realizacji doświadczenia hermeneutycznego", w: Gadamer, Prawda, 544. 
Analiza teorii Czystej Formy pozwala na odróżnienie od siebie dwóch rodzajów sztuki: 1) sztuki formistycznej, która wymaga interpretacji formistycznej, obiektywizuje i generuje uczucia metafizyczne oraz jest elitarna; 2) sztuki realistycznej, wymagającej interpretacji realistycznej, obiektywizującej i generującej uczucia życiowe, egalitarnej.

Sztuką w ścisły sensie byłaby tylko pierwsza z nich. Określenie piękna życiowego jako „związanego z użytkowością życiową przedmiotu lub zjawiska" 21 prowadzi do utożsamienia interpretacji realistycznej z postawą praktyczną, właściwą dla funkcjonowania indywiduum w codziennej praktyce życiowej, skutkuje również sprowadzeniem sztuki realistycznej do działań wytwórczych odbywających się w ramach owej praktyki. Nie bez powodu działalność swej Firmy Portretowej Witkacy traktował jako pragmatyczną produkcję rzemieślniczą.

Relacje pomiędzy obszarami sztuki formistycznej i życia praktycznego (sztuki realistycznej) nie są neutralne. Witkiewicz używa tu określenia „walka z treścią życiową":

[...] przezwyciężając materiał życiowy, czyni artysta z niego tylko pretekst do napięć kierunkowych i dynamicznych i dla zabarwień jakościowych, tworząc oderwane konstrukcje formalne. Oczywiście rozwój ten musi być osiągnięty w sposób naturalny, a nie programowy ${ }^{22}$.

Walka z życiową treścią w sztuce jest historią zawiłą i ciężką i czasami nie można wymagać od danego artysty zupełnej ciągłości rozwoju i konsekwencji w stosunku do jego teoretycznych, a nawet nie ujętych pojęciowo, założeń, które z prac jego poprzednich wydedukować by można ${ }^{23}$.

Wydaje się, że walce z treścią życiową należy przyznać rangę istotową dla sztuki w ogóle. Znaczące w tym względzie są uwagi Witkiewicza, w których przedstawia on realizm jako szczególną anomalię w dziejach sztuki, moment deformacji logicznego ciągu rozwojowego, będący skutkiem dotychczas niespotykanej $\mathrm{w}$ dziejach kulturowej dominacji pragmatycznych aspektów egzystencji ${ }^{24}$. Taka perspektywa pozwala mu określać własny program artystyczny jako „odrodzenie Czystej Formy" 25 tożsame z powrotem sztuki pod władzę reguł jej własnego procesu rozwojowego. Pojmowanie odrodzonego formizmu w jego perwersyjnej postaci jako reaktywacji zdezaktualizowanych form wrażliwości estetycznej świadczy o sprzeczności pomiędzy procesami rozwojowymi sztuki i życia społecznego. Formistyczna finalizacja dziejów sztuki do-

21 Witkiewicz, O czystej formie, 56.

22 Tamże, 65.

23 Tamże.

24 Tamże, 64.

25 Tamże, 49. 
konuje się wbrew pragmatycznym determinantom progresu cywilizacyjnego. Formizm okazuje się walką z treścią życiową również jako akt zderzenia logiki rozwoju sztuki z prawami postępu społecznego.

\section{Komplementarność formy i życia}

Wbrew wszelkim racjom przemawiającym za przyznaniem sprzeczności pomiędzy sztuką formistyczną i realistyczną kluczowej roli w teorii Czystej Formy można odnaleźć argumenty na rzecz komplementarności owych przeciwieństw. W pierwszym rzędzie takim argumentem musi być wspomniana już wyżej niemożliwość ścisłego odgraniczenia formizmu od realizmu ${ }^{26}$. Argument drugi to tezy Witkiewicza uprawniające do pojmowania uczucia metafizycznego jako procesu sensotwórczej integracji. Otóż uczucie to zostaje przedstawione jako fundament praktyki egzystencjalnej istot żywych.

Uczucie metafizyczne, czyli [...] bezpośrednio [...] dana jedność osobowości, w stanie normalnego, życiowego nastawienia, [...] jest przyczyną niepokoju życiowego: utrzymania się indywiduum wśród przeciwności dookolnego świata, jego oddychania, szukania pożywienia, rozmnażania się itd. W stanie uwolnionym, $\mathrm{tzn}$. jako takie uświadomione, staje się uczucie to przyczyną tego, co nazywam "niepokojem metafizycznym": stanu, w którym przeciwstawienie się osobowości żywego stworzenia zewnętrznemu światu zarysowuje się w świadomości ostro i wyraźnie jako takie ${ }^{27}$.

Zwróćmy uwagę na odróżnienie nieświadomej postaci uczucia metafizycznego od jego formy uświadomionej. Pierwsza z postaci jest przyczyną działań praktycznych służących podtrzymaniu życia. Druga realizuje się jako doświadczenie autonomii indywiduum, poczucie jego odrębności od otoczenia stanowi więc zasadę indywiduacji (principium individuationis). Co więcej, uczucie metafizyczne określone jako poczucie jedność osobowości zostaje wskazane jako korelat procesu rejestrowania „kompleksów jakości”, konstytutywnego dla obszaru doświadczenia zmysłowego.

Takimi kompleksami jakości (np. barw kształtów lub dotyków) ujętymi w prawidłowe, powtarzające się w pewnych granicach związki będą też

26 Tamże, 63.

27 Tegoż, O znaczeniu filozofii dla krytyki i inne artykuty polemiczne. Pisma filozoficzne i estetyczne, t. 2, oprac. Jan Leszczyński (Warszawa: PWN, 1976), 53. 
przedmioty świata zewnętrznego: „materia martwa” i ciała innych istot żyjących ${ }^{28}$.

W tak podanej charakterystyce kluczową rolę pełni idea integracji elementów w sensowne całości. „Otóż każdy, nawet najbardziej chaotyczny kompleks jakości ma pewien p or zą d e k29" .

Zarówno przedmiot poznania, jak i poznający podmiot (względnie działająca istota żywa) zostają potraktowane jako zbiory elementów zintegrowane w sensowne całości. Przy tym pojęciem, które zostaje użyte dla oddania charakteru związków pomiędzy elementami owych całości, jest kategoria związku funkcjonalnego.

Wszystko, co muszę tu rozłożyć na elementy, a następnie przedstawić w czasie, jest danym, że tak powiem dla skrócenia, od razu; jednak w tej „od razowości” nie może być pojęciowo przedstawione ${ }^{30}$.

W rzeczywistości mamy istotnie jedynie związki funkcjonalne, które dla celów praktycznych rozbijamy na oddzielne kompleksy, nazywając je przyczynami i skutkami. Jednak w poglądzie życiowym musimy dla ekonomii działania zachować te ostatnie pojęcia, zdając sobie sprawę, że są to, z teoretycznego punktu widzenia, jedynie przybliżenia ${ }^{31}$.

Odróżnienie związku funkcjonalnego od dyskursywnej kategoryzacji przyczynowo-skutkowej oraz pragmatycznej perspektywy życia sugeruje, że poziom zintegrowanych ,jedności w wielości” wyprzedza zarówno dyskurs przyczynowo-skutkowy, jak i pragmatykę życia codziennego. Jeśli uczucie metafizyczne ma być psychicznym korelatem owych związków funkcjonalnych, mamy pełne prawo przyjąć, że istotą owego uczucia jest sensotwórcza integracja. To, co zostaje dane świadomości w postaci uczucia metafizycznego, to podmiotowa, zintegrowana całość sensu o wyraźnej (choć niekoniecznie dyskursywnie wyartykułowanej) tożsamości wyodrębnionej z tła o radykalnie odmiennej kwalifikacji. Obecność owej tożsamości (czy to w postaci świadomego ja, czy też przeciwstawionego swemu środowisku, nieświadomego podmiotu zabiegów utrzymywania się przy życiu) sugeruje, że nie idzie tu o jakieś dowolne agregaty, lecz o autoteliczne, dynamiczne związki znaczeń będące pochodnymi pre-dyskursywnych procesów stanowienia sensu.

Jednakże ruch integracji elementów odrębnych w sensowne całości jest obecny nie tylko na pre-dyskursywnym planie elementarnych pro-

\footnotetext{
28 Tamże, 30.

29 Tamże, 31.

30 Tamże, 53.

31 Tamże, 54.
} 
cesów życiowych. Taka przecież jest również istota Witkiewiczowskich praw rozwoju społecznego.

[...] każdy musi zgodzić się na to, że rozwój ludzkości idzie, zaczynając od najpierwotniejszego zrzeszenia, $\mathrm{w}$ kierunku upośledzenia indywiduum na rzecz tego zrzeszenia, przy czym indywiduum to, $\mathrm{w}$ zamian za pewne wyrzeczenia się, otrzymuje inne korzyści, których by samo osiągnąć nie mogło. Podporządkowanie interesów jednostki interesom ogółu - oto najogólniejsze ujęcie tego procesu, który nazywamy uspołecznieniem ${ }^{32}$.

Postępująca integracja podstawowych elementów życia społecznego - indywiduów - w coraz bardziej złożone, wyspecjalizowane, efektywne całości służy zoptymalizowaniu zaspokajania potrzeb życiowych owych elementów. Ale ponieważ świat ludzki nie jest wyjątkiem, a każde indywiduum jest agregatem elementów, ów proces integracji musi prowadzić do powstania indywiduum wyższego rzędu. „[...] hiperorganizmy są możliwe [...], Najwyższa Istota - o ile jest, zwracam uwagę: ostateczny sceptycyzm jest nie do uniknięcia - jest absolutnym automatem" 33 .

Uczucie metafizyczne winniśmy zatem traktować jako korelat psychiczny całego spektrum form sensotwórczej integracji. Najprostszą z nich byłaby indywidualna aktywność egzystencjalna, najbardziej złożoną - zmechanizowane życie społeczne. Ponieważ siłą napędową procesu sensotwórczej integracji jest uczucie metafizyczne, likwidacja tego uczucia, a zarazem likwidacja autonomii indywiduów składowych, musi być tożsama z celem całej procedury. Teleologiczna dynamika procesu sensotwórczej integracji nadaje owemu procesowi charakter autodestrukcyjny dla jego istoty - uczucia metafizycznego. Będzie ono możliwe wyłącznie na etapach pośrednich procesu, przysługując elementom niedostatecznie zintegrowanym. Być może zatem uczucie metafizyczne winno być traktowane nie tyle jako psychiczny korelat procesu sensotwórczej integracji, lecz jako symptom niepełności owego procesu, jako efekt swoistego deficytu sensu. Wówczas fundamentem tożsamości indywiduum okazywałaby się świadomość własnej ułomności, pojawiająca się wraz z rozpoznaniem siebie jako niesuwerennego, ale też niewystarczająco zintegrowanego elementu nadsubiektywnego ruchu, zmierzającego ku idealności sensotwórczej integracji.

Pamiętając, że finałem procesu dziejowego jest dla Witkiewicza mechanizacja życia społecznego, zauważmy stosowanie do tak określonego telos dwóch wykluczających się perspektyw: etycznej, z której widoczne

32 Tegoż, Nowe formy w malarstwie i wynikajace stąd nieporozumienia. Pisma filozoficzne i estetyczne, t. 1 (Warszawa: PWN, 1974), 100.

33 Tegoż, Oni, w: Dramaty I, oprac. Janusz Degler (Warszawa: PIW, 2016), 442. 
jest optimum powszechnego szczęścia i współpracy ${ }^{34}$, oraz estetycznej, z której widać katastrofę kultury ${ }^{35}$. Obecność owych dwóch perspektyw zdaje się korespondować z dwoma aspektami uczucia metafizycznego. Przecież uczucie to jest nie tylko korelatem sensotwórczej integracji (poczucia jedności w wielości), ale też indywidualizującej kontestacji przeciwstawienia się indywiduum obcemu dlań światu.

Twierdzę, że Sztuka jest wyrazem tego, co z braku lepszego terminu nazywam „uczuciem metafizycznym” i co definiuję jako bezpośrednio, a nie rozumowo, daną jedność osobowości, czyli jedność naszego „ja”, w przeciwstawieniu do nieskończonej wielości całości Istnienia ${ }^{36}$.

Drugi aspekt uczucia metafizycznego odsyła do Witkiewiczowskiej kategorii Tajemnicy Istnienia. Również w definicji Tajemnicy zostaje użyta formuła , „jedności w wielości”. „Tajemnicą istnienia jest jedność w wielości i nieskończoność jego tak w małości, jak i w wielkości, przy jednoczesnej koniecznej ograniczoności każdego Istnienia Poszczególnego" ${ }^{\prime 3}$.

Doświadczenie Tajemnicy Istnienia możemy chyba traktować jako objawienie zagadkowości samego procesu sensotwórczej integracji. Również ono posiada dwa aspekty: negatywny i pozytywny. Aspekt negatywny ujawnia się jako „potworność i groza" ${ }^{38}$ paraliżujące aktywność egzystencjalną indywiduum i wymagające specjalnych narzędzi (religii, sztuki i filozofii) dla neutralizacji swej destrukcyjnej mocy. Wynikiem neutralizacji byłaby aktywizacja aspektu pozytywnego. Ten zaś realizowałby się w odczuciu „,metafizycznej tajemnicy bez potwornego osamotnienia we wszechświecie" ${ }^{\prime \prime 2}$. W ten sposób religia, sztuka i filozofia dokonywałyby rewaluacji Tajemnicy Istnienia ${ }^{40}$.

Starając się myślą oznaczyć granice niezgłębionej tajemnicy Istnienia, widzimy dopiero świat w jego istotnej wewnętrznej piękności. Każda chwila naszego życia, w której możemy to pojmować, nabiera nieskończonej absolutnej wartości, a śmierć nie jest potworną otchłanią od której uciekamy pod skrzydła jakiegokolwiek Fetysza obiecującego nam żywot wieczny, tylko koniecznym prawem Istnienia, za cenę potworności ży-

34 Tegoż, Nowe formy, 100.

35 Tamże.

36 Tegoż, O znaczeniu, 11.

37 Tegoż, Nowe formy, 6.

38 Tamże, 105.

39 Tamże, 110.

40 Mariusz Oziębłowski, „Społeczny kontekst poznawczego paraliżu filozofii w ujęciu Stanisława Ignacego Witkiewicza", w: Filozofia polska na tle filozofii europejskiej w XX wieku, red. Maciej Woźniczka (Częstochowa: Akademia im. Jana Długosza w Częstochowie, 2014), 379. 
ciowej którego byliśmy i mogliśmy choć na chwilę pojmować jedność i piękno wszechrzeczy ${ }^{41}$.

Skoro funkcją sztuki ma być neutralizacja destrukcyjnego potencjału Tajemnicy, a istnieją dwa rodzaje sztuki, czy w takim razie obie biorą udział $\mathrm{w}$ akcie rewaluacji?

Ponieważ sztuka realistyczna jest elementem pragmatyki życia codziennego, winniśmy uznać ją za efekt i składową procesów modernizacji życia społecznego. Jeśli jednak uczestniczy ona w procesie rozwoju społecznego, czyli mechanizacji życia, dlaczego jej treścią nie są uczucia metafizyczne będące przecież korelatem sensotwórczej integracji?

Z kolei sztuka formistyczna zostaje określona jako „walka z treścią życiową" ${ }^{42}$, musi więc być traktowana jako wyraz i narzędzie aktów indywidualizacji, kontestujących proces sensotwórczej integracji. „Sztuka jest [...] zaprzeczeniem Istoty Najwyższej, którą jest nieskończony hiperorganizm" ${ }^{\prime 4}$.

Jeśli sztuka formistyczna jest obiektywizacją i źródłem uczucia metafizycznego, a ono jest psychicznym korelatem sensotwórczej integracji, to dlaczego nie miałaby być składową procesu mechanizacji? Przecież sztuka formistyczna, dokonując rewaluacji Tajemnicy Istnienia, umożliwia rozwój cywilizacji. Jako warunek możliwości cywilizacji sztuka formistyczna pełni względem mechanizacji funkcję transcendentalną.

Rozpoznanie funkcji transcendentalnej sztuki formistycznej uprawnia do twierdzenia o komplementarności formizmu i realizmu. Mimo przeciwstawnych charakterystyk oba rodzaje sztuki stanowią składowe procesu mechanizacji. Sztuka realistyczna, przekazując uczucia życiowe oraz odwzorowując rzeczywistość, pełni funkcję poznawczą i integrującą (tak jak dziewiętnastowieczny realizm w malarstwie polskim był stosowany jako środek budzenia solidarności szlachty i ludu oraz narzędzie ekspozycji społecznych problemów wsi) ${ }^{44}$. Jednak ani integracja, ani postęp społeczny nie byłyby możliwe bez równoległej, formistycznej neutralizacji destrukcyjnego potencjału Tajemnicy.

\section{Przeciwieństwo poznania i integracji}

Teza o komplementarności formizmu i realizmu jest zbieżna z obecnym w filozofii Gadamera przekonaniem o komplementarności dwóch

${ }^{41}$ Witkiewicz, Nowe formy, 123.

42 Tegoż, O czystej formie, 65.

43 Tegoż, „Oni”, 442.

44 Malinowski, Malarstwo, 137. 
funkcji doświadczenia hermeneutycznego: integrującej i poznawczej ${ }^{45}$. Jednak wśród badaczy spuścizny Witkiewicza można napotkać pogląd o obecnym w teorii Czystej Formy, zasadniczym konflikcie funkcji poznawczej i integrującej. W utracie złudzeń co do możliwości integrującego działania sztuki upatruje wyższości Witkacego nad modernistami XIX wieku Jan Błoński:

Nie przychodziło im nawet do głowy, że to właśnie sztuka - podniesiona do religijnej godności - nie może podołać funkcjom, którymi została obarczona. Już tym różni się katastrofizm Witkacego od pesymizmu modernistów. Dla artystów początku wieku sztuka jest bez skazy i ponad wszelkim podejrzeniem. Dla Witkacego jest sojuszniczką możnych, nawet wbrew własnej woli. Właśnie dlatego, że „uczucie metafizyczne" tajemnicza istność, w której spotykają się religia, filozofia, sztuka - nie może scalić społeczności, dostarczając jej etycznych norm i praktycznych wskazówek. Co ma być ponad wszystkim, nie musi być dla wszystkich. Ale winno wszystko ogarnąć; porządkować - lepiej czy gorzej - całokształt ludzkiego doświadczenia. Tymczasem Witkacy nie miał już złudzeń co do wydolności sztuki. Podkreślał więc anachronizm kultu, którego był żarliwym wyznawcą ${ }^{46}$.

Co może świadczyć o sprzeczności pomiędzy funkcją poznawczą i integrującą? Przede wszystkim wspomniane już określenie interpretacji formistycznej jako „walki z treścią życiową". Walka ta polega przecież na minimalizowaniu albo eliminacji z doświadczenia sztuki uczuć życiowych. W ich miejscu winny pojawić się uczucia metafizyczne. Jednak - jak już wiemy - transcendentalna funkcja formizmu polega na neutralizacji destrukcyjnego potencjału Tajemnicy Istnienia (transformacji negatywnego aspektu w pozytywny).

Jeśli Witkiewicz restytuuje ideę Czystej Formy wbrew realistycznym determinantom modernistycznej mechanizacji świata, a czyni to, pragnąc ponownie przywoływać wypierane $\mathrm{w}$ procesie postępu społecznego uczucia metafizyczne, to przecież nie może mu chodzić o transcendentalną funkcję formizmu. Reaktywacja uczuć metafizycznych w dominium realizmu musi być zatem odwrotnością funkcji transcendentalnej. Jeśli odróżniliśmy od siebie dwa aspekty Tajemnicy Istnienia i dwa aspekty uczucia metafizycznego, a także wskazaliśmy transformację aspektu negatywnego w pozytywny jako funkcję sztuki formistycznej, to być może należałoby również rozważyć możliwość przemiany odwrotnej.

45 Por.: „Wszelako w tej przemianie rozumienia dochodzi do głosu sama rzecz, o której tekst traktuje. Podobnie jak w rzeczywistej rozmowie tym, co wiąże partnerów - tu interpretatora z tekstem - jest wspólna rzecz" (Gadamer, Prawda, 524).

46 Jan Błoński, Witkacy na zawsze (Kraków: Wydawnictwo Literackie, 2003), 53. 
Taka przemiana musiałby oznaczać destrukcję mechanistycznych struktur sensu, kontestację pragmatyki życia, restytucję wszystkich eliminowanych $\mathrm{w}$ procesie socjalizacji elementów antagonizujących indywiduum względem swego środowiska. Owa restytucja wymagałaby regresu do wcześniejszych stadiów kultury. Faktem jest wielokrotna obecność w pismach Witkacego motywów, takich jak "odrodzenie się bezsensu samego w sobie" ${ }^{\prime 7}$ i "cofnięcie kultury"48. Figura "cofnięcia kultury" zostaje użyta dla wyrażenia pesymizmu historiozoficznego: „[...] człowiek stworzył kulturę, która przerastała jego siły, a ponieważ rozwoju jej cofnąć (przynajmniej na razie) nie może, musi zginąć pod jej ciężarem" ${ }^{\prime 4}$.

Zauważmy tutaj, że postrzeganie cofnięcia kultury jako aktu nierealizowalnego w skali globalnej nie niweczy możliwości daremnych, acz doraźnie satysfakcjonujących prób kulturowego regresu w skali indywidualnej. Tak pojęta interpretacja formistyczna musiałaby realizować się jako indywidualizująca destrukcja związków sensu. Jeśli uznać, że dramaty i literatura Witkiewicza mają być narzędziami takiej destrukcji, należałoby wykazać, że nie pełnią one żadnych aspektów poznawczych ani integrujących. Można wątpić, czy doświadczenie sztuki, którego źródłem są dramaty Witkacego, rzeczywiście niweczy możliwość powstawania wspólnot rozumienia $\mathrm{w}$ hermeneutycznym sensie. Dowodem istnienia takiego integrującego wpływu musi być nie tylko stosunkowa popularność owych sztuk, ale też istnienie zinstytucjonalizowanego środowiska miłośników i znawców twórczości Witkiewicza. Łatwo też wskazać poznawcze walory dramatów i powieści - choćby w starannie przemyślanym i konsekwentnym wykładzie historiozoficznej wizji Witkiewicza. Czy fakt, że sztuka Witkacego cechuje się zaskakującą trafnością prognostyczną i diagnostyczną w dziedzinie zmian społecznych i kulturowych, podaje w wątpliwość jej postulowaną tutaj destrukcyjną istotę?

Oczywiście najprościej stwierdzić, że dzieła Witkacego są jedynie poronionymi próbami realizacji formistycznego ideału i dowodami klęski w walce z treścią życiową. (Sam Witkiewicz wielokrotnie dyskredytował efekty swych prac). Zważmy jednak, że treścią tej sztuki jest dokonujący się i nadchodzący kulturowy kataklizm, dziejowa katastrofa, względem której wszelkie indywidualne wysiłki kontestacji muszą okazać się daremne. Opowieść o chybionych próbach realizacji Czystej Formy to opowieść o przegranej walce z wszechmocą mechanizacji. A więc treścią

47 Stanisław Ignacy Witkiewicz, Maciej Korbowa i Bellatrix, w: Dramaty I, oprac. Janusz Degler (Warszawa: PIW, 2016), 116.

48 Tegoż, Tumor Mózgowicz, w: Dramaty I (Warszawa: PIW, 2016), 255.

49 Tegoż, Narkotyki - Niemyte dusze, oprac. Anna Micińska (Warszawa: PIW, 1975), 214. 
sztuki formistycznej nie jest uczucie metafizyczne, lecz jego negatywny aspekt - doświadczenie katastrofy.

Chcemy poddać pod rozwagę możliwość takiej koncepcji sztuki formistycznej, której celem byłoby odwrócenie rewaluacji uczucia metafizycznego (Tajemnicy Istnienia). Sztuka ta stanowiłaby kontestację aktywności sensotwórczej integracji, transformującą ją w jej przeciwieństwo - doświadczenie katastrofy. Nie pełniłaby funkcji poznawczej w sensie epistemologicznym, lecz ontologicznym - byłaby epifanią Tajemnicy Istnienia. Miałaby zatem negatywną wartość poznawczą. Nie pełniłaby też żadnej funkcji integrującej. Byłaby destrukcją struktur sensu tworzacych proces mechanizacji. Taka dezintegracja sensu stanowiłaby również odwrotność funkcji transcendentalnej. Performatywna detranscendentalizacja kwestionowałaby w samych podstawach proces konstytucji wspólnot rozumienia. Nie byłaby tylko opowieścią o doświadczeniu katastrofy, neutralizującą jej destrukcyjny potencjał. Byłaby realizacją katastrofy w pełni jej niszczącej mocy.

Oczywiście takie doświadczenie musiałoby okazać się destrukcyjne nie tylko $w$ teoretycznym sensie. A podstawową przeszkodą w jego realizacji byłyby niezbędne $\mathrm{w}$ praktyce egzystencjalnej rudymentarne akty stanowienia sensu. Ostatecznie walka z treścią życiową to walka z samym życiem. A nie ma chyba prawdy groźniejszej dla życia niż ta, że postęp społeczny jest tożsamy z zagładą człowieczeństwa.

\section{Podsumowanie}

Treścią pracy była rekonstrukcja teorii Czystej Formy za pomocą kategorii i rozwiązań wypracowanych w filozofii hermeneutycznej Gadamera. Przedstawiając uczucie metafizyczne jako psychiczny korelat procesów sensotwórczej integracji, wskazaliśmy integrującą i poznawczą funkcję sztuki realistycznej oraz transcendentalną funkcję sztuki formistycznej jako komplementarne narzędzia procesów integracji konstytutywnych dla obszarów doświadczenia zmysłowego oraz rozwoju społecznego.

W drugiej części pracy rozważaliśmy możliwość takiej formuły sztuki formistycznej, w której jest ona elementem nie komplementarnym, lecz wykluczającym względem sztuki realistycznej. W tym przypadku sztuka formistyczna (i odpowiednio - interpretacja formistyczna) poczęła się jawić jako medium (narzędzie ekspozycji?) doświadczenia katastrofy, reaktywującego destrukcyjny potencjał Tajemnicy Istnienia i niszczącego nawet dla rudymentarnych aktów stanowienia sensu, będących podstawą ludzkiej praktyki życiowej.

Tak określona formuła sztuki formistycznej musiałaby okazać się kontestacją procesów sensotwórczej integracji w obszarach doświadczenia zmysłowego oraz życia społecznego. Konieczność odróżniania 
dwóch postaci formizmu (komplementarnej oraz wykluczającej względem realizmu) wydaje się wyjaśniać, w jaki sposób sztuka formistyczna może jednocześnie pełnić wykluczające się funkcje, transcendentalną oraz destrukcyjna, względem procesów sensotwórczej integracji.

\section{Bibliografia}

Błoński Jan. 2003. Witkacy na zawsze. Kraków: Wydawnictwo Literackie.

Gadamer Hans-Georg. 1993. Aktualność piękna. Sztuka jako gra, symbol i święto, przeł. Krystyna Krzemieniowa. Warszawa: Oficyna Naukowa.

Gadamer Hans-Georg. 2004. Prawda i metoda. Zarys hermeneutyki filozoficznej, przeł. Bogdan Baran. Warszawa: PWN.

Gadamer Hans-Georg. 2000. Rozum, słowo, dzieje. Szkice wybrane, przeł. Małgorzata Łukasiewicz, Krzysztof Michalski, Warszawa: PIW.

Grondin Jean. 2007. Wprowadzenie do hermeneutyki filozoficznej, przeł. Leszek Łysień. Kraków: Wydawnictwo WAM.

Malinowski Jerzy. 2003. Malarstwo polskie XIX wieku. Warszawa: Wydawnictwo DiG.

Oziębłowski Mariusz. 2014. „Społeczny kontekst poznawczego paraliżu filozofii w ujęciu Stanisława Ignacego Witkiewicza". W: Filozofia polska na tle filozofii europejskiej w XX wieku, red. Maciej Woźniczka, 365-381. Częstochowa: Akademia im. Jana Długosza w Częstochowie.

Soin, Maciej. 2002. Filozofia Stanisława Ignacego Witkiewicza. Wrocław: Wydawnictwo UWr.

Witkiewicz Stanisław Ignacy. 2003. „O czystej formie” $i$ inne pisma o sztuce, oprac. Janusz Degler. Warszawa: PIW.

Witkiewicz Stanisław Ignacy. 1976. „O znaczeniu filozofii dla krytyki” $i$ inne artykuty polemiczne. Pisma filozoficzne i estetyczne, t. 2, oprac. Jan Leszczyński. Warszawa: PWN.

Witkiewicz Stanisław Ignacy. 1974. Nowe formy w malarstwie i wynikajace stad nieporozumienia. Pisma filozoficzne i estetyczne, t. 1, oprac. Jan Leszczyński. Warszawa: PWN.

Witkiewicz Stanisław Ignacy. „Oni”. W: Dramaty I, oprac. Janusz Degler, 403-464. Warszawa: PIW, 2016.

Witkiewicz Stanisław Ignacy. 2016. „Maciej Korbowa i Bellatrix”. W: Dramaty I, oprac. Janusz Degler, 83-176. Warszawa: PIW.

Witkiewicz Stanisław Ignacy. 2016. „Tumor Mózgowicz”. W: Dramaty I, oprac. Janusz Degler, 209-218. Warszawa: PIW.

Witkiewicz Stanisław Ignacy. 1975. Narkotyki - Niemyte dusze, oprac. Anna Micińska. Warszawa: PIW.

Witkiewicz Stanisław. 1972. O sztuce, krytyce artystycznej, stylu zakopiańskim, wybitnych twórcach, sprawach społecznych, oprac. Wanda Nowakowska. Wrocław: Zakład Narodowy im. Ossolińskich. 


\section{Streszczenie}

Przedmiotem rozważań jest filozofia sztuki Stanisława Ignacego Witkiewicza. Autor prezentuje podstawowe funkcje dzieła sztuki oraz analizuje ich związki z kategoriami realizmu i Czystej Formy. Rozważane są również związki funkcji sztuki z tezami historiozoficznym Witkiewicza.

Słowa kluczowe: filozofia sztuki, funkcje sztuki, Stanisław Ignacy Witkiewicz, filozofia historii, doświadczenie katastrofy

\section{Summary}

\section{Functions of Art in Stanisław Ignacy Witkiewicz's Theory of Pure Form}

The matter under consideration is Stanisław Ignacy Witkiewicz's philosophy of art. The author presents basic functions of a work of art and analyzes their connections with the categories of realism and Pure Form. In addition, the author considers the relations between the functions of art and Witkiewicz's philosophy of history.

Keywords: philosophy of art, functions of art, Stanisław Ignacy Witkiewicz, philosophy of history, experience of disaster 